\title{
Front Matter: Volume 7237
}

, "Front Matter: Volume 7237," Proc. SPIE 7237, Stereoscopic Displays and Applications XX, 723701 (24 February 2009); doi: 10.1117/12.827576

SPIE Event: IS\&T/SPIE Electronic Imaging, 2009, San Jose, California, United SPIE. States 


\title{
PROCEEDINGS \\ IS\&T/SPIE \\ Electronia \\ meging \\ Science and Technology
}

\section{Stereoscopic Displays and Applications XX}

\author{
Andrew J. Woods \\ Nicolas S. Holliman \\ John O. Merritt \\ Editors
}

19-21 January 2009

San Jose, California, United States

Sponsored and Published by

IS\&T-The Society for Imaging Science and Technology

SPIE

Principal Sponsor

IMAX (Canada)

Projection Sponsors

DepthQ Stereoscopic (United States)

JVC Professional (United States)

Christie Digital Systems USA, Inc. (United States)

Kerner Optical (United States) 
The papers included in this volume were part of the technical conference cited on the cover and title page. Papers were selected and subject to review by the editors and conference program committee. Some conference presentations may not be available for publication. The papers published in these proceedings reflect the work and thoughts of the authors and are published herein as submitted. The publishers are not responsible for the validity of the information or for any outcomes resulting from reliance thereon.

Please use the following format to cite material from this book:

Author(s), "Title of Paper," in Stereoscopic Displays and Applications XX, edited by Andrew J. Woods, Nicolas S. Holliman, John O. Merritt, Proceedings of SPIE-IS\&T Electronic Imaging, SPIE Vol. 7237, Article CID Number (2009).

ISSN 0277-786X

ISBN 9780819474872

Copublished by

SPIE

P.O. Box 10, Bellingham, Washington 98227-0010 USA

Telephone +1 3606763290 (Pacific Time) · Fax +1 3606471445

SPIE.org

and

IS\&T-The Society for Imaging Science and Technology

7003 Kilworth Lane, Springfield, Virginia, 22151 USA

Telephone +1 7036429090 (Eastern Time) · Fax +1 7036429094

imaging.org

Copyright (C) 2009, Society of Photo-Optical Instrumentation Engineers and The Society for Imaging Science and Technology.

Copying of material in this book for internal or personal use, or for the internal or personal use of specific clients, beyond the fair use provisions granted by the U.S. Copyright Law is authorized by the publishers subject to payment of copying fees. The Transactional Reporting Service base fee for this volume is $\$ 18.00$ per article (or portion thereof), which should be paid directly to the Copyright Clearance Center (CCC), 222 Rosewood Drive, Danvers, MA 01923. Payment may also be made electronically through CCC Online at copyright.com. Other copying for republication, resale, advertising or promotion, or any form of systematic or multiple reproduction of any material in this book is prohibited except with permission in writing from the publisher. The CCC fee code is 0277-786X/09/\$18.00.

Printed in the United States of America.

Paper Numbering: Proceedings of SPIE follow an e-First publication model, with papers published first online and then in print and on CD-ROM. Papers are published as they are submitted and meet publication criteria. A unique, consistent, permanent citation identifier (CID) number is assigned to each article at the time of the first publication. Utilization of CIDs allows articles to be fully citable as soon they are published online, and connects the same identifier to all online, print, and electronic versions of the publication. SPIE uses a six-digit CID article numbering system in which:

- The first four digits correspond to the SPIE volume number.

- The last two digits indicate publication order within the volume using a Base 36 numbering system employing both numerals and letters. These two-number sets start with 00, 01, 02, 03, 04, 05, 06, 07 , $08,09,0 \mathrm{~A}, \mathrm{OB} \ldots \mathrm{OZ}$, followed by 10-1Z, 20-2Z, etc.

The CID number appears on each page of the manuscript. The complete citation is used on the first page, and an abbreviated version on subsequent pages. Numbers in the index correspond to the last two digits of the six-digit CID number. 


\title{
Contents
}

\author{
xi Conference Committee \\ xiii Introduction
}

\section{APPLICATIONS OF STEREOSCOPY}

723702 From bench to bedside: stereoscopic imaging in experimental and clinical otology [7237-01]

J. Ilgner, S. Biedron, M. Bovi, RWTH Aachen Univ. (Germany); E. Fadeeva, Laser Zentrum Hannover e.V. (Germany); M. Westhofen, RWTH Aachen Univ. (Germany)

723703 Stereoscopic display technologies, interaction paradigms, and rendering approaches for neurosurgical visualization [7237-02]

J. R. Cooperstock, G. Wang, McGill Univ. (Canada)

723704 Case study: using a stereoscopic display for mission planning [7237-03]

M. Kleiber, C. Winkelholz, Research Establishment for Applied Science (Germany)

723705 3D vision system assessment [7237-04]

J. L. Pezzaniti, R. Edmondson, J. Vaden, B. Hyatt, D. B. Chenault, Polaris Sensor Technologies (United States); D. Kingston, V. Geulen, S. Newell, Concurrent Technologies Corp. (United States); B. Pettijohn, Army Research Lab. (United States)

723706 Autostereoscopic display of large-scale scientific visualization [7237-05] T. Peterka, R. Ross, Argonne National Lab. (United States); H. Yu, Sandia National Labs. (United States); K.-L. Ma, Univ. of California, Davis (United States); R. Kooima, Univ. of Illinois at Chicago (United States); J. Girado, Qualcomm Inc. (United States)

\section{MULTIVIEW AND LIGHTFIELD TECHNOLOGIES}

723707 Spatial-angular analysis of displays for reproduction of light fields [7237-06]

A. Said, Hewlett-Packard Labs. (United States); E.-V. Talvala, Stanford Univ. (United States)

723708 Flat panel display with slanted pixel arrangement for 16-view display [7237-07]

Y. Takaki, Tokyo Univ. of Agriculture and Technology (Japan); O. Yokoyama, G. Hamagishi, Seiko Epson Corp. (Japan)

723709 High-density light field reproduction using overlaid multiple projection images [7237-08] M. Yamasaki, H. Sakai, K. Utsugi, T. Koike, Hitachi, Ltd. (Japan)

7237 OA Calibrating camera and projector arrays for immersive 3D display [7237-09]

H. Baker, Hewlett-Packard Labs. (United States); Z. Li, Univ. of California, Berkeley (United States); C. Papadas, Integrated Systems Development S.A. (Greece) 
7237 OB Three-dimensional television: a broadcaster's perspective [7237-11]

S. J. E. Jolly, M. Armstrong, R. A. Salmon, British Broadcasting Corp. (United Kingdom)

7237 OC Stereoscopic CG camera rigs and associated metadata for cinematic production [7237-114]

S. Sylwan, Autodesk, Inc. (United States); D. MacDonald, J. Walter, Autodesk Canada Co. (Canada)

7237 OD A modular projection autostereoscopic system for stereo cinema [7237-67] V. A. Elkhov, N. V. Kondratiev, Y. N. Ovechkis, L. V. Pautova, NIKFI (Russian Federation)

7237 OE Digital stereoscopic convergence where video games and movies for the home user meet [7237-14]

E. Schur, TDVision Sytems, Inc. (United States)

\section{DIGITAL 3D STEREOSCOPIC ENTERTAINMENT II}

7237 OF Bolt 3D: a case study [7237-115]

R. Neuman, Walt Disney Animation Studios (United States)

$7237 \mathrm{OH} \quad$ Optimizing 3D image quality and performance for stereoscopic gaming [7237-17] J. Flack, H. Sanderson, S. Pegg, S. Kwok, D. Paterson, Dynamic Digital Depth Research Pty. Ltd. (Australia)

$7237 \mathrm{Ol}$ Evaluating methods for controlling depth perception in stereoscopic cinematography [7237-18]

G. Sun, N. Holliman, Durham Univ. (United Kingdom)

7237 0J Publishing stereoscopic images [7237-19]

R. Labbe, Studio 3D (United States); D. E. Klutho, 3D Illustrated (United States)

\section{STEREOSCOPIC HUMAN FACTORS}

7237 OK Measuring visual discomfort associated with 3D displays [7237-21]

M. Lambooij, Eindhoven Univ. of Technology (Netherlands) and Philips Research Labs. (Netherlands); M. Fortuin, Eindhoven Univ. of Technology (Netherlands), Hogeschool Utrecht (Netherlands), and City Univ. (United Kingdom); W. A. ljsselsteijn, Eindhoven Univ. of Technology (Netherlands); I. Heynderickx, Philips Research Labs. (Netherlands) and Delft Univ. of Technology (Netherlands)

$7237 \mathrm{OL} \quad$ Evaluation of stereoscopic 3D displays for image analysis tasks [7237-22]

E. Peinsipp-Byma, N. Rehfeld, R. Eck, Fraunhofer Institute for Information and Data Processing (Germany)

7237 OM Binocular coordination in response to stereoscopic stimuli [7237-23] S. P. Liversedge, Univ. of Southampton (United Kingdom); N. S. Holliman, Durham Univ. (United Kingdom); H. I. Blythe, Univ. of Southampton (United Kingdom) 
7237 ON The compatibility of LCD TVs with time-sequential stereoscopic 3D visualization [7237-24] A. J. Woods, A. Sehic, Curtin Univ. of Technology (Australia)

723700 Color holographic reconstruction using multiple SLMs and LED illumination [7237-25]

F. Yaraş, L. Onural, Bilkent Univ. (Turkey)

7237 OP Review of wire grid polarizer and retarder for stereoscopic display [7237-26]

S. J. Lee, M. J. Kim, K. H. Lee, K. H. Park, Pavonine Korea, Inc. (Korea, Republic of)

$7237 \mathrm{OQ} \quad$ Using mental rotation to evaluate the benefits of stereoscopic displays [7237-92]

Y. Aitsiselmi, N. S. Holliman, Durham Univ. (United Kingdom)

7237 OR Stereo display with time-multiplexed focal adjustment [7237-28]

D. M. Hoffman, Univ. of California at Berkeley (United States); P. J. W. Hands, A. K. Kirby,

G. D. Love, Durham Univ. (United Kingdom); M. S. Banks, Univ. of California at Berkeley

(United States)

\section{AUTOSTEREOSCOPIC DISPLAYS}

7237 OS Large real-time holographic displays: from prototypes to a consumer product [7237-29] R. Häussler, S. Reichelt, N. Leister, E. Zschau, R. Missbach, A. Schwerdtner, SeeReal Technologies GmbH (Germany)

7237 OT High-definition integral floating display with multiple spatial light modulators [7237-30] J. Kim, K. Hong, J.-H. Jung, G. Park, J. Lim, Y. Kim, J. Hahn, Seoul National Univ. (Korea, Republic of); S.-W. Min, Kyung Hee Univ. (Korea, Republic of); B. Lee, Seoul National Univ. (Korea, Republic of)

7237 OU OLED backlight for autostereoscopic displays [7237-31]

U. Vogel, L. Kroker, K. Seidl, J. Knobbe, Ch. Grillberger, J. Amelung, M. Scholles, Fraunhofer Institute for Photonic Microsystems (Germany)

7237 OV Autostereoscopic projector and display screens [7237-33]

S. Zacharovas, R. Bakanas, E. Kuchin, Geola Digital uab (Lithuania)

\section{STEREOSCOPIC DEVELOPMENTS I}

7237 OW Effect of light ray overlap between neighboring parallax images in autostereoscopic 3D displays [7237-34]

R. Fukushima, K. Taira, T. Saishu, Y. Momonoi, M. Kashiwagi, Y. Hirayama, Toshiba Corp. (Japan)

7237 OX Shutter glasses stereo LCD with a dynamic backlight [7237-35]

J.-C. Liou, K. Lee, Industrial Technology Research Institute (Taiwan) and National Tsing Hua Univ. (Taiwan); F.-G. Tseng, National Tsing Hua Univ. (Taiwan); J.-F. Huang, W.-T. Yen,

W.-L. Hsu, Industrial Technology Research Institute (Taiwan) 
7237 OZ A new way to characterize autostereoscopic 3D displays using Fourier optics instrument [7237-37]

P. Boher, T. Leroux, T. Bignon, V. Collomb-Patton, ELDIM (France)

$723710 \quad$ Effects of sampling on depth control in integral imaging [7237-38]

J. Arai, M. Kawakita, F. Okano, NHK (Japan)

723712 Compressed stereoscopic video quality metric [7237-40]

J. Seo, D. Kim, K. Sohn, Yonsei Univ. (Korea, Republic of)

723713 Coherent spatial and temporal occlusion generation [7237-54]

R. Klein Gunnewiek, R.-P. M. Berretty, Philips Research Eindhoven (Netherlands):

B. Barenbrug, Philips 3D Solutions Eindhoven (Netherlands); J. P. Magalhães, Philips Research Eindhoven (Netherlands)

\section{STEREOSCOPIC DEVELOPMENTS II}

723714 Stereoscopy in cinematographic synthetic imagery [7237-42]

J. Eisenmann, R. Parent, The Ohio State Univ. (United States)

723715 Compressive acquisition of ray-space using radon transform [7237-43]

K. Yamashita, T. Yendo, M. Tanimoto, Nagoya Univ. (Japan); T. Fujii, Tokyo Institute of Technology (Japan)

723716 The effect of 2D/3D environment on decision making confidence in visual perceptual tasks [7237-44]

S. Negry, Tel Aviv Univ. (Israel) and Mantis Vision (Israel); M. First, Mantis Vision (Israel)

723717 Experiments on shape perception in stereoscopic displays [7237-45]

L. Leroy, P. Fuchs, A. Paljic, CAOR, Mines ParisTech (France); G. Moreau, Ecole Centrale Nantes (France)

723718 Depth and distance perception in a curved large screen virtual reality installation [7237-46] D. Gadia, Univ. of Milan (Italy); A. Galmonte, Univ. of Verona (Italy); T. Agostini, Univ. of Trieste (Italy); A. Viale, D. Marini, Univ. of Milan (Italy)

\section{D TO 3D CONVERSION}

723719 Depth map quality metric for three-dimensional video [7237-47]

D. Kim, D. Min, Yonsei Univ. (Korea, Republic of); J. Oh, Yonsei Univ. (Korea, Republic of) and Korean Broadcasting System (Korea, Republic of); S. Jeon, Korean Broadcasting System (Korea, Republic of); K. Sohn, Yonsei Univ. (Korea, Republic of)

7237 1A Three-dimensional TV: a novel method for generating surrogate depth maps using colour information [7237-48]

W. J. Tam, C. Vázquez, F. Speranza, Communications Research Ctr. Canada (Canada) 
7237 1B Unsupervised object segmentation for 2D to 3D conversion [7237-49]

M. Kunter, S. Knorr, imcube, Technische Univ. Berlin (Germany); A. Krułz, T. Sikora, Technische

Univ. Berlin (Germany)

\section{D ON MOBILE DEVICES}

7237 1C Digital stereoscopic photography using StereoData Maker [7237-50]

J. Toeppen, HoloGraphics (United States); D. Sykes, Consultant (United Kingdom)

7237 1D Stereoscopic contents authoring system for 3D DMB data service [7237-51]

B. Lee, K. Yun, N. Hur, J. Kim, S. Lee, Electronics and Telecommunications Research Institute (Korea, Republic of)

7237 1E Evaluation of stereoscopic image quality for mobile devices using interpretation based quality methodology [7237-52]

T. Shibata, S. Kurihara, T. Kawai, Waseda Univ. (Japan); T. Takahashi, T. Shimizu, R. Kawada, A. Ito, KDDI R\&D Labs., Inc. (Japan); J. Häkkinen, Univ. of Helsinki (Finland) and Nokia Research Ctr. (Finland); J. Takatalo, G. Nyman, Univ. of Helsinki (Finland)

7237 IF Classification and simulation of stereoscopic artifacts in mobile 3DTV content [7237-53]

A. Boev, D. Hollosi, A. Gotchev, K. Egiazarian, Tampere Univ. of Technology (Finland)

\section{DEPTH MAP TECHNIQUES}

7237 1G Declipse 2: multi-layer image and depth with transparency made practical [7237-41]

B. Barenbrug, Philips 3D Solutions (Netherlands)

7237 1H Efficient and automatic stereoscopic videos to $\mathbf{N}$ views conversion for autostereoscopic displays [7237-55]

D. Alessandrini, R. Balter, S. Pateux, Orange Labs., France Telecom R\&D (France)

7237 II Depth camera for 3DTV applications [7237-84]

J. Kim, T. Kim, Electronics and Telecommunications Research Institute (Korea, Republic of);

W.-J. Kim, Korea Advanced Institute of Science and Technology (Korea, Republic of); N. Hur, Electronics and Telecommunications Research Institute (Korea, Republic of)

\section{INTERACTIVE PAPER SESSION}

7237 i Application of stereoscopic arc photogrammetry to image-guided radiation therapy and treatment planning [7237-57]

C. D. Brack, I. L. Kessel, L. French, J. Clewlow, M. Wolski, Univ. of Texas Medical Branch (United States)

7237 1K Temporal sub-sampling of depth maps in depth image-based rendering of stereoscopic image sequences [7237-58]

W. J. Tam, F. Speranza, C. Vázquez, L. Zhang, Communications Research Ctr. Canada (Canada) 
7237 IL Indirect ophthalmoscopic stereo video system using three-dimensional LCD [7237-59] H.-J. Kong, J. M. Seo, J. M. Hwang, H. C. Kim, Seoul National Univ. (Korea, Republic of)

7237 IM Stereoscopic camera system with creator-friendly functions [7237-60]

S. Kishi, N. Abe, T. Shibata, T. Kawai, Waseda Univ. (Japan); M. Maeda, K. Hoshi, Flovel Co., Ltd. (Japan)

723710 The development of the integrated-screen autostereoscopic display system [7237-62] W.-L. Hsu, W.-L. Chen, C.-H. Tsai, C.-L. Wang, C.-S. Wu, Y.-C. Chen, S.-C. Cheng, Industrial Technology Research Institute (Taiwan)

7237 IP A method for evaluating motion sickness induced by watching stereoscopic images on a head-mounted display [7237-63]

H. Takada, Gifu Univ. of Medical Science (Japan); K. Fujikake, Institute for Science of Labour (Japan); T. Watanabe, Aichi Gakuin Univ. (Japan); S. Hasegawa, Nagoya Bunri Univ.

(Japan); M. Omori, Kobe Women's Univ. (Japan); M. Miyao, Nagoya Univ. (Japan)

$72371 Q$ Dense light field microscopy [7237-65]

Y.-T. Lim, J.-H. Park, N. Kim, K.-C. Kwon, Chungbuk National Univ. (Korea, Republic of)

7237 IR A common interface for stereo viewing in various environments [7237-66]

O. Pariser, R. G. Deen, Jet Propulsion Lab. (United States)

7237 is Resizing of stereoscopic images for display adaptation [7237-71]

W.-J. Kim, S.-D. Kim, Korea Advanced Institute of Science and Technology (Korea,

Republic of); J. Kim, N. Hur, Electronics and Telecommunications Research Institute (Korea, Republic of)

7237 IT Super multi-view display with 128 viewpoints and viewpoint formation [7237-72] Y. Takaki, Tokyo Univ. of Agriculture and Technology (Japan)

7237 IU A novel 2D-to-3D conversion technique based on relative height-depth cue [7237-73] Y. J. Jung, A. Baik, J. Kim, D. Park, Samsung Advanced Institute of Technology (Korea, Republic of)

7237 IV 3D and 2D switchable display [7237-74] M. Nagashima, Consultant (Japan)

7237 IW SOLIDFELIX: a transportable 3D static volume display [7237-75]

K. Langhans, A. Kreft, H. T. Wörden, Vincent-Luebeck-High-School (Germany)

7237 1X High speed large viewing angle shutters for triple-flash active glasses [7237-77]

B. Caillaud, B. Bellini, J. L. de Bougrenet de la Tocnaye, TELECOM Bretagne (France)

7237 IY Spatial-coding-based 2D/3D/P-P display [7237-78]

H. Yamamoto, S. Suyama, The Univ. of Tokushima (Japan)

7237 IZ A wavelet-based quadtree driven stereo image coding [7237-79]

R. Bensalma, M.-C. Larabi, XLIM Lab., CNRS, Univ. of Poitiers (France) 
723720 All in focus plane reconstruction based on integral imaging [7237-82]

G. Baasantseren, J.-H. Park, N. Kim, Chungbuk National Univ. (Korea, Republic of)

$723721 \quad$ Hybrid depth cueing for 2D-to-3D conversion system [7237-85]

C.-C. Cheng, C.-T. Li, Y.-M. Tsai, L.-G. Chen, National Taiwan Univ. (Taiwan)

723722 Optically multilayered light field display for enhancing depth of field [7237-86]

T. Wada, The Univ. of Tokyo (Japan); T. Koike, The Univ. of Tokyo (Japan) and Hitachi, Ltd.

(Japan); T. Naemura, The Univ. of Tokyo (Japan)

723723 Real-time rendering for integral photography that uses extended fractional view [7237-87]

K. Yanaka, Kanagawa Institute of Technology (Japan)

$723724 \quad$ High-speed liquid-crystal optical deflector for 3D display [7237-88]

S. Wakita, Y. Sumitomo, Y. Kobayashi, The Univ. of Tokushima (Japan)

723725 The variance estimation and enhanced 3D sensing of heavily occluded objects using synthetic aperture integral imaging (SAII) [7237-89]

Y. S. Hwang, E.-S. Kim, Kwangwoon Univ. (Korea, Republic of)

723726 Improving image quality of coarse integral volumetric display [7237-90]

H. Kakeya, Univ. of Tsukuba (Japan)

Author Index 
Downloaded From: https://www.spiedigitallibrary.org/conference-proceedings-of-spie on 26 Apr 2023

Terms of Use: https://www.spiedigitallibrary.org/terms-of-use 


\title{
Conference Committee
}

\author{
Symposium Chair \\ Nitin Sampat, Rochester Institute of Technology (United States) \\ Symposium Cochair \\ Jan P. Allebach, Purdue University (United States) \\ Conference Chairs
}

Andrew J. Woods, Curtin University of Technology (Australia)

Nicolas S. Holliman, Durham University (United Kingdom)

John O. Merritt, The Merritt Group (United States)

Program Committee

Neil A. Dodgson, University of Cambridge (United Kingdom)

Gregg E. Favalora, Actuality Medical, Inc. (United States)

Takashi Kawai, Waseda University (Japan)

Janusz Konrad, Boston University (United States)

Shojiro Nagata, Japan 3D Forum/InterVision (Japan)

Vivian K. Walworth, Jasper Associates (United States)

Chris Ward, Lightspeed Design, Inc. (United States)

Michael A. Weissman, TrueVision Systems (United States)

\section{Session Chairs}

1 Applications of Stereoscopy

John O. Merritt, The Merritt Group (United States)

2 Multiview and Lightfield Technologies

Neil A. Dodgson, University of Cambridge (United Kingdom)

3 Digital 3D Stereoscopic Entertainment I

Andrew J. Woods, Curtin University of Technology (Australia)

4 Digital 3D Stereoscopic Entertainment II

Chris Ward, Lightspeed Design, Inc. (United States)

5 Keynote Presentation

Andrew J. Woods, Curtin University of Technology (Australia) 
6 Stereoscopic Human Factors

John O. Merritt, The Merritt Group (United States)

$7 \quad 3 D$ Displays

Gregg E. Favalora, Actuality Medical, Inc. (United States)

8 Autostereoscopic Displays

Nicolas S. Holliman, Durham University (United Kingdom)

9 Stereoscopic Developments I

Vivian K. Walworth, Jasper Associates (United States)

103 3 Image Processing and Image Quality

Takashi Kawai, Waseda University (Japan)

11 Stereoscopic Developments II

Takashi Kawai, Waseda University (Japan)

12 2D to 3D Conversion

Michael A. Weissman, TrueVision Systems (United States)

13 3D on Mobile Devices

Nicolas S. Holliman, Durham University (United Kingdom)

14 Depth Map Techniques

Neil A. Dodgson, University of Cambridge (United Kingdom) 


\section{Introduction}

The 20th annual Stereoscopic Displays and Applications conference took place 19-21 January 2009 as part of the 2009 IS\&T/SPIE Electronic Imaging: Science and Technology Symposium, and was held at the San Jose McEnery Convention Center, San Jose, California, USA. This proceedings volume contains the technical papers in support of the presentations and posters given at the 20th annual SD\&A conference. This introduction gives an overview of the conference: a reminder for those who attended and an insight into what happened for those who were unable to attend. We also take an opportunity to celebrate the first 20 years of the conference.

Twenty years is an impressive milestone for any conference. Stereoscopic imaging has changed considerably over those 20 years and the SD\&A conference has served a valuable role in tracking those developments. The most visible product of those 20 years is the impressive collection of proceedings volumes:

\begin{tabular}{|c|c|c|c|c|c|}
\hline Year & $\begin{array}{l}\text { Conference } \\
\text { (Name and Number) }\end{array}$ & Location & $\begin{array}{l}\text { Proc. } \\
\text { SPIE } \\
\text { Vol. }\end{array}$ & $\begin{array}{l}\text { Published in } \\
\text { Volume (name) }\end{array}$ & SD\&A Conference Chairs \\
\hline 1990 & $\begin{array}{l}\text { Stereoscopic Displays } \\
\text { and Applications }\end{array}$ & $\begin{array}{l}\text { Santa } \\
\text { Clara }\end{array}$ & 1256 & $\begin{array}{l}\text { Stereoscopic } \\
\text { Displays and } \\
\text { Applications }\end{array}$ & $\begin{array}{l}\text { John O. Merritt, } \\
\text { Scott S. Fisher }\end{array}$ \\
\hline 1991 & $\begin{array}{l}\text { Stereoscopic Displays } \\
\text { and Applications II }\end{array}$ & San Jose & 1457 & $\begin{array}{l}\text { Stereoscopic } \\
\text { Displays and } \\
\text { Applications II }\end{array}$ & $\begin{array}{l}\text { John O. Merritt, } \\
\text { Scott S. Fisher }\end{array}$ \\
\hline 1992 & $\begin{array}{l}\text { Stereoscopic Displays } \\
\text { and Applications III }\end{array}$ & San Jose & 1669 & $\begin{array}{l}\text { Stereoscopic } \\
\text { Displays and } \\
\text { Applications III }\end{array}$ & $\begin{array}{l}\text { John O. Merritt, } \\
\text { Scott S. Fisher }\end{array}$ \\
\hline 1993 & $\begin{array}{l}\text { Stereoscopic Displays } \\
\text { and Applications IV }\end{array}$ & San Jose & 1915 & $\begin{array}{l}\text { Stereoscopic } \\
\text { Displays and } \\
\text { Applications IV }\end{array}$ & $\begin{array}{l}\text { John O. Merritt, } \\
\text { Scott S. Fisher }\end{array}$ \\
\hline 1994 & $\begin{array}{l}\text { Stereoscopic Displays } \\
\text { and Applications V }\end{array}$ & San Jose & 2177 & $\begin{array}{l}\text { Stereoscopic } \\
\text { Displays and Virtual } \\
\text { Reality Systems }\end{array}$ & $\begin{array}{l}\text { Scott S. Fisher, } \\
\text { John O. Merritt }\end{array}$ \\
\hline 1995 & $\begin{array}{l}\text { Stereoscopic Displays } \\
\text { and Applications VI }\end{array}$ & San Jose & 2409 & $\begin{array}{l}\text { Stereoscopic } \\
\text { Displays and Virtual } \\
\text { Reality Systems II }\end{array}$ & $\begin{array}{l}\text { Scott S. Fisher, } \\
\text { John O. Merritt }\end{array}$ \\
\hline 1996 & $\begin{array}{l}\text { Stereoscopic Displays } \\
\text { and Applications VII }\end{array}$ & San Jose & 2653 & $\begin{array}{l}\text { Stereoscopic } \\
\text { Displays and Virtual } \\
\text { Reality Systems III }\end{array}$ & $\begin{array}{l}\text { Scott S. Fisher, } \\
\text { John O. Merritt }\end{array}$ \\
\hline 1997 & $\begin{array}{l}\text { Stereoscopic Displays } \\
\text { and Applications VIII }\end{array}$ & San Jose & 3012 & $\begin{array}{l}\text { Stereoscopic } \\
\text { Displays and Virtual } \\
\text { Reality Systems IV }\end{array}$ & $\begin{array}{l}\text { Scott S. Fisher, } \\
\text { John O. Merritt }\end{array}$ \\
\hline
\end{tabular}




\begin{tabular}{|c|c|c|c|c|c|}
\hline 1998 & $\begin{array}{l}\text { Stereoscopic Displays } \\
\text { and Applications IX }\end{array}$ & San Jose & 3295 & $\begin{array}{l}\text { Stereoscopic } \\
\text { Displays and Virtual } \\
\text { Reality Systems } V\end{array}$ & $\begin{array}{l}\text { Scott S. Fisher, } \\
\text { John O. Merritt }\end{array}$ \\
\hline 1999 & $\begin{array}{l}\text { Stereoscopic Displays } \\
\text { and Applications X }\end{array}$ & San Jose & 3639 & $\begin{array}{l}\text { Stereoscopic } \\
\text { Displays and Virtual } \\
\text { Reality Systems VI }\end{array}$ & $\begin{array}{l}\text { John O. Merritt, } \\
\text { Scott S. Fisher }\end{array}$ \\
\hline 2000 & $\begin{array}{l}\text { Stereoscopic Displays } \\
\text { and Applications XI }\end{array}$ & San Jose & 3957 & $\begin{array}{l}\text { Stereoscopic } \\
\text { Displays and Virtual } \\
\text { Reality Systems VII }\end{array}$ & $\begin{array}{l}\text { John O. Merritt, } \\
\text { Stephen A. Benton, } \\
\text { Andrew J. Woods }\end{array}$ \\
\hline 2001 & $\begin{array}{l}\text { Stereoscopic Displays } \\
\text { and Applications XII }\end{array}$ & San Jose & 4297 & $\begin{array}{l}\text { Stereoscopic } \\
\text { Displays and Virtual } \\
\text { Reality Systems VIII }\end{array}$ & $\begin{array}{l}\text { Andrew J. Woods, } \\
\text { John O. Merritt, } \\
\text { Stephen A. Benton }\end{array}$ \\
\hline 2002 & $\begin{array}{l}\text { Stereoscopic Displays } \\
\text { and Applications XIII }\end{array}$ & San Jose & 4660 & $\begin{array}{l}\text { Stereoscopic } \\
\text { Displays and Virtual } \\
\text { Reality Systems IX }\end{array}$ & $\begin{array}{l}\text { Andrew J. Woods, } \\
\text { John O. Merritt, } \\
\text { Stephen A. Benton }\end{array}$ \\
\hline 2003 & $\begin{array}{l}\text { Stereoscopic Displays } \\
\text { and Applications XIV }\end{array}$ & $\begin{array}{l}\text { Santa } \\
\text { Clara }\end{array}$ & 5006 & $\begin{array}{l}\text { Stereoscopic } \\
\text { Displays and Virtual } \\
\text { Reality Systems X }\end{array}$ & $\begin{array}{l}\text { Andrew J. Woods, } \\
\text { John O. Merritt, } \\
\text { Stephen A. Benton }\end{array}$ \\
\hline 2004 & $\begin{array}{l}\text { Stereoscopic Displays } \\
\text { and Applications XV }\end{array}$ & San Jose & 5291 & $\begin{array}{l}\text { Stereoscopic } \\
\text { Displays and Virtual } \\
\text { Reality Systems XI }\end{array}$ & $\begin{array}{l}\text { Andrew J. Woods, } \\
\text { John O. Merritt, } \\
\text { Stephen A. Benton }\end{array}$ \\
\hline 2005 & $\begin{array}{l}\text { Stereoscopic Displays } \\
\text { and Applications XVI }\end{array}$ & San Jose & 5664 & $\begin{array}{l}\text { Stereoscopic } \\
\text { Displays and Virtual } \\
\text { Reality Systems XII }\end{array}$ & $\begin{array}{l}\text { Andrew J. Woods, } \\
\text { John O. Merritt }\end{array}$ \\
\hline 2006 & $\begin{array}{l}\text { Stereoscopic Displays } \\
\text { and Applications XVII }\end{array}$ & San Jose & 6055 & $\begin{array}{l}\text { Stereoscopic } \\
\text { Displays and Virtual } \\
\text { Reality Systems XIII }\end{array}$ & $\begin{array}{l}\text { Andrew J. Woods, } \\
\text { Neil A. Dodgson, } \\
\text { John O. Merritt }\end{array}$ \\
\hline 2007 & $\begin{array}{l}\text { Stereoscopic Displays } \\
\text { and Applications XVIII }\end{array}$ & San Jose & 6490 & $\begin{array}{l}\text { Stereoscopic } \\
\text { Displays and Virtual } \\
\text { Reality Systems XIV }\end{array}$ & $\begin{array}{l}\text { Andrew J. Woods, } \\
\text { Neil A. Dodgson, } \\
\text { John O. Merritt }\end{array}$ \\
\hline 2008 & $\begin{array}{l}\text { Stereoscopic Displays } \\
\text { and Applications XIX }\end{array}$ & San Jose & 6803 & $\begin{array}{l}\text { Stereoscopic } \\
\text { Displays and } \\
\text { Applications XIX }\end{array}$ & $\begin{array}{l}\text { Andrew J. Woods, } \\
\text { Nick S. Holliman, } \\
\text { John O. Merritt }\end{array}$ \\
\hline 2009 & $\begin{array}{l}\text { Stereoscopic Displays } \\
\text { and Applications XX }\end{array}$ & San Jose & 7237 & $\begin{array}{l}\text { Stereoscopic } \\
\text { Displays and } \\
\text { Applications XX }\end{array}$ & $\begin{array}{l}\text { Andrew J. Woods, } \\
\text { Nick S. Holliman, } \\
\text { John O. Merritt }\end{array}$ \\
\hline
\end{tabular}

Equally as important as the technical outputs of the conference are the people who have attended and contributed to making this conference such an enjoyable meeting to attend over those 20 years.

Returning to the present-this year's conference was the best attended since the series began. There was a broad range of topics, presentations, and events; and, of course, we celebrated the first twenty years of the conference series.

The first day had four technical sessions, a lunchtime discussion, the 3D theatre, and the 20th anniversary banquet. The four technical sessions covered Applications of Stereoscopy (chaired by John Merritt), Multiview and Lightfield Technologies (chaired by Neil Dodgson), and two sessions on Digital 3D 
Stereoscopic Entertainment (chaired by Andrew Woods and Chris Ward). The technical sessions form the backbone of the conference, and their content is detailed in the papers contained in this volume.

The two-hour 3D Theatre Session (chaired by Andrew Woods and Chris Ward) is a regular event that showcases how 3D video is being used and produced around the world. This year, we screened the following 3D content (or segments thereof) on the conference's two high-quality circularly polarized stereoscopic rearprojection systems:

- "Scarecrow" by Cinema and Photo Research Institute (Russia) and Animation studio NUKUFILM (Estonia)

- "Corner" by Pietro Carlomagno (music: Riccardo Castaldi)

- "Legends of the Sky" (in production) (preview footage) by K2

- "Mr Egg - The Great Magician" by Bronislav Vavrinka and GALI-3D s.r.o.

- "Bubble Hunters" by Dan Ridley-Ellis (Napier University, Edinburgh, UK)

- "Milky Way" by Tokyo Polytechnic University

- "Plane Fancy" by Thomas R. Koester

- "Time Voyagers" by UBIK Visual Effects (Milano), Dario Piana, Franco Valenziano, and Jean Cristophe Casalini for Gardaland

- "The Witch Way" by 3D Experience (UK)

- "3xperimentia" by Team 3xperimentia (Australia)

- "Colours of Australia" by Jumbo Vision International and Gerhard Kimenkowski

- "Delusion 3D" by Virtual Experience (Germany)

- "Reminiscence" by Celine Tricart (France)

- "Czech National Forest" by Forests Czech Republic n.p., Communication agency Kristian s.r.o. and GALI-3D s.r.o.

- "MAIJISHAN GROTTO" by Waseda University, Toppan Printing, and Peking University

- "Bajraroad" by Andrzej Waluk (Poland)

- "Fireworks Symphony" by Takashi Sekitani, StereoEye (Japan)

- "Bigger than Big" by Swinburne University of Technology (Australia)

- "The Little Things" by Swinburne University of Technology (Australia)

- "Mine Lifeline LLC" by Dzignlight Studios

- "Menger Abstraction" by Dzignlight Studios

- "Ghost Car" by John Hart and Stereo Club of southern California

- "The making of Slow Glass" by Thomas R. Koester

- "Image Fusion, 3DHD Brain Surgery" by tree-D Films and TrueVision Systems, Inc.

- "LRO Scouts for Safe Landing Sites" by Helen-Nicole Kostis, University of Maryland Baltimore County and Scientific Visualization Studio, GSFC/NASA

- "Scalable City" by Sheldon Brown, The Experimental Game Lab, CRCA, UCSD

- "Yosemite 3D" (Preview Trailer) by 3D Film Factory

- "Mermaid Parade" by Stone Circle Productions

- "The Curse of Skull Rock" by Ben Smith, Red Star 3D (UK)

- "Spatial Art: A Thousand Year of Thought" by NHK Media Technology(Japan) 
- "3ality Digital show reel" by 3ality Digital

- "Portal" by Justin Knowles and DDD

- "Wanderlust" by Byork and Encyclopediapictura

- "Call of the Wild 3D" by 21st Century 3D

- "Daimajin" by Kadokawa Pictures, Arisawa Mfg, and Waseda University (Japan)

- "Bolt 3D" by Disney

- "Ultimate Wave" (in production) (preview footage) by K2

- "Coraline 3D" by Laika Studios

This two-hour session was the most popular session of the conference, with over 250 attendees filling the room. The purpose of this session is to showcase the great range of 3D content that is being produced around the world, and we certainly achieved that goal this year.

In recognition of the high quality of material shown at the 3D Theatre, we again offered two 'Best of Show' prizes. Our judges, Dr. Samuel Zhou (Director of Image Technology at IMAX Corporation, Canada) and Lawrence Kaufman (President, National Stereoscopic Association) chose the winning titles:

- Best of Show (Computer Graphics): "Scaleable City" by Sheldon Brown, The Experimental Game Lab, CRCA, UCSD

- Best of Show (Live Action): "Fireworks Symphony" by Takashi Sekitani, StereoEye (Japan)

Each of the prize winners received a specially autographed copy of the new 3D book In Your Face 3D by Sports Illustrated photographer David Klutho and 3D artist Ron Labbe. Congratulations to our winners on their beautiful work.

An illustrated listing of the content shown during this year's 3D Theatre session will be available from the conference website: www.stereoscopic.org/3dcinema

The evening concluded with a special 20th anniversary banquet at the BoTown Chinese Restaurant in downtown San Jose. Approximately 100 conference attendees mingled, talked, and ate in a relaxed atmosphere. After dinner, Andrew Woods and John Merritt gave an illustrated talk about the early days of the conference, including photos of the conference chairs at a much younger age.

The second day of the SD\&A conference had the keynote presentation, the demonstration session, the poster session, a lunchtime discussion, and six technical sessions.

The six technical sessions covered Human Factors (chaired by John Merritt), Stereoscopic Developments (two sessions chaired by Vivian Walworth and 
Takashi Kawai), 3D Displays (chaired by Gregg Favalora), Autostereoscopic Displays (chaired by Nick Holliman), and 3D Image Processing (chaired by Takashi Kawai). For the first time, we had so many papers that we had to run parallel sessions on this day. The technical sessions were followed by the poster session, with a record 23 posters this year. The full papers from the technical sessions and posters are contained in this volume.

The keynote presentation, titled "Archimedes' Tub," was given by Lenny Lipton, who shares with John Merritt the distinction of having attended every SD\&A conference in the 20-year series. Lenny gave an entertaining personal tour through the history of stereoscopic displays, and also provided some personal perspectives on his attendance at the SD\&A conference over the 20 years.

The final event of the day was the ever-popular Demonstration Session, which has run every year since 1990. Since 2006, this has been a symposium-wide event, open to demonstrators from all 22 Electronic Imaging conferences. It was pleasing to see a wide variety of stereoscopic imaging systems on display and to see a large audience actively engaging with the various displays and vendors. To our knowledge this annual event is the biggest collection of 3D displays in any one location in North America and has been so for many years.

This year the following 3D hardware and software products were on show at the demonstration session:

- University of Durham, UK (Geng Sun and Nick Holliman) used a Sharp LL-1513D 15" autostereoscopic display to demonstrate their study, which empirically evaluated three depth mapping approaches.

- Pavonine, Korea (Keith Park and Sung Jung Lee) showed a prototype 5.5" wire-grid micro-polarizer stereoscopic 3D display viewed using passively polarized 3D glasses and two other prototype 3D displays.

- Fraunhofer Institute for Photonic Microsystems, Germany (Michael Scholles) showed an autostereoscopic 3D display with an OLED backlight that allowed multi-user display without reduction of geometrical resolution.

- Polaris Sensor Technologies, USA (Rich Edmondson and Larry Pezzaniti) demonstrated several stereoscopic flat panel 3D display systems, with live and digital inputs, viewed using passively polarized 3D glasses, and two stereoscopic video camera systems.

- Philips 3D Solutions, The Netherlands (Bart Barenbrug and Rene Klein Gunnewiek) showed a WOWvx large screen autostereoscopic 3D display capable of rendering the new 2D+depth format extension presented at the conference, as well as a smaller autostereoscopic 3D photo-frame display.

- Communications Research Center, Canada (James Tam) showed autostereoscopic images converted from 2D DVD in real-time on a 20" Philips 3D monitor.

- HoloGraphics, California (John and Brian Toeppen) showed a stereoscopic digital still camera rig using a pair of Canon cameras and StereoData Maker 
software, as well as a large collection of stereo-pairs viewed using a selection of stereoscopes.

- Caltech/JPL, California (Oleg Pariser) demonstrated a new software infrastructure for building stereoscopic display applications in Java, and several applications for stereo viewing utilizing imaging data from NASA Mars surface missions. A stereoscopic panorama of the surface of Mars was viewable across two Sony monitors using NuVision LCS 3D glasses.

- Tokyo University of Agriculture \& Technology, Japan (Yasuhiro Takaki) and Seiko Epson Corporation, Japan (Tomio Sonehara) showed a 16-view autostereoscopic 3D display using a slanted pixel structured LCD panel.

- Kanagawa Institute of Technology, Japan (Kazuhisa Yanaka) used a notebook computer with fly's eye lenses to show simple 3D objects consisting of a few triangles, rendered and displayed autostereoscopically in real time. Two autostereoscopic still images were also on display using this same method.

- Tokushima University, Japan (Shota Wakita and Hirotsugu Yamamoto) demonstrated a high-speed liquid-crystal optical deflector suitable for 3D display.

- Hewlett-Packard Company, California (Harlyn Baker) made a valiant attempt to setup a multiple projector autostereoscopic 3D display for teleconferencing purposes, but encountered some technical hurdles.

- University of Tsukuba, Japan (Hideki Kakeya) demonstrated a coarse integral volumetric imaging display that can show autostereoscopic images without contradiction between convergence and accommodation.

- NVIDIA Corporation, California (David Cook, Andrew Fear, and Michael McSorley) showed high-quality stereoscopic 3D gaming rendering on two Samsung $120 \mathrm{~Hz}$ 3D LCD panels, viewed using the new wireless NVIDIA GeForce 3D Vision LCS glasses driven by a pair of Alienware Gaming PCs.

- DepthQ Stereoscopic, Washington (Chris Ward and Dan Lawrence) demonstrated the DepthQ HD 3D projector, viewed using the NVIDIA GeForce 3D Vision LCS glasses, and driven by a PC running DepthQ stereoscopic media server software.

- Intravista LLC, California (Wei SU) demonstrated an LCOS 3D front projector with HD resolution powered by an LED light source, viewed using circularly polarized 3D glasses. This was the first public demonstration of this new projector.

- TDVision Systems, Illinois (Ethan Schur) used a Hyundai 46" Vuon 3D LCD, viewed using circularly polarized 3D glasses, to demonstrate TDVision's stereoscopic software solutions for stereoscopic video encoding (TDVision Codec), gaming and virtual worlds, as well as the TDVisor stereoscopic head mounted display.

- ETRI (Electrical and Telecommunications Research Institute), Korea (Gwang Soon Lee and Bong Ho Lee) used two handheld devices with autostereoscopic screens to demonstrate a DIBR(Depth Image Based Rendering)-based 3D DMB (Digital Multimedia Broadcast) service, which 
provides 3D mobile broadcasting service using DIBR technologies over Terrestrial DMB.

- Bare Hill Software Company, New York (Richard Bolton) demonstrated a personal stereographic viewer for 2D digital images and video.

There were also several stereoscopic items at the Electronic Imaging Exhibition in the main concourse on Tuesday and Wednesday:

- The 3D Consortium (Japan) facilitated the exhibition of stereoscopic products from member companies: TDVision Systems (Illinois) showed a similar setup to their demonstration session booth described above, and Mark Resources (California) demonstrated a 60" diagonal full-color autostereoscopic 3D backlit transparency print of fluorescent minerals.

- $\quad$ NHK Enterprises America (NEPA) (Japan) demonstrated their stereoscopic 3D HD content acquisition services and 3D HD content library using a JVC 46" 3D LCD micro-polarizer monitor, viewed using circularly polarized 3D glasses.

- Faced with a never-ending flow of 3D professionals at their stand, the staff on the Matlab stand got smart and used a cell-phone camera to quickly capture and create an anaglyph 3D image using their Matlab software. You have to admire their inventiveness.

Also in the exhibit area was the annual Phantogram Exhibit, organized by Terry Wilson from Terryfic3D. Phantograms are a fascinating 3D art form that allows the illusion to be created of real objects sitting in the space in front of you. A very good pair of anaglyph 3D prints created by Terry succinctly demonstrated the difference between a phantogram and a regular 3D image. As well as showing a vast collection of Terry's own 3D phantograms, the exhibit included works from the following phantogram artists: Gilbert Detillieux, Dennis Wiens, David Kesner, Jim Gasperini, Dan Jacob, Barry Rothstein, Shab Levy, and John Ballou. We were very fortunate to be able to re-route one of the Phantogram postal portfolios to San Jose and have this on display as part of the exhibit.

Throughout the conference we were fortunate to have on exhibit almost twodozen large framed anaglyph 3D prints from the book, In Your Face 3D, by David Klutho. Seeing the long line of $3 D$ prints setup along the wall outside the conference room was certainly an impressive sight. A book signing was also organized during the conference for attendees to get the book personally autographed.

An extensive photo montage and listing of the demonstration session and exhibits from this year's SD\&A conference will be available on the conference website: www.stereoscopic.org

The third day of the SD\&A conference had three technical sessions and two discussion forums. The technical sessions covered 2D to 3D Conversion (chaired by Mike Weissman), 3D on Mobile Devices (chaired by Nick Holliman), and Depth 
Map Techniques (chaired by Neil Dodgson). The papers from these technical sessions are contained in this volume.

This year we had two Discussion Forums. The first considered Standards to Enable Ubiquitous 3D Display. The panel, chaired by Nick Holliman, consisted of Mike Robinson (RealD, USA), James Tam (CRC, Canada), Howard Postley, (3ality Digital, USA), and Jeroen Brouwer (Philips 3D Solutions, USA). The second panel asked "3D Gaming: What is it going to take to go big time?" The panel was chaired by Neil Schneider from MTBS3D (Canada) and the panelists were Andrew Fear (NVIDIA Corporation, USA), Bob Eminian (iZ3D LLC, USA), Julien Flack (Dynamic Digital Depth, USA), and Chris Ward (Lightspeed Design Inc, USA). The discussion forums always provide an interesting venue for the open discussion of topics of wide interest to the stereoscopic community. As with previous years, there was again good interaction with the audience, with several questions coming from the floor during both discussion forums.

Several sessions at this year's SD\&A conference were video recorded: the keynote presentation, the discussion forums, and the papers in the double technical session "Digital 3D Stereoscopic Entertainment." Editing is underway and we plan to progressively make the content available via the conference website through the year.

Two prizes were offered at the conference for the best use of the stereoscopic projection tools during the technical presentations. Many presentations used stereoscopic projection as an integral part of their presentations and the two winners, chosen by the SD\&A conference chairs, were:

- "Publishing stereoscopic images" by Ron Labbe (Studio 3D, USA). Ron's entire presentation consisted of polarized stereoscopic images that covered the history of stereoscopic images in the published form. In an interesting, twist he also demonstrated both anaglyph and polarized 3D viewing methods on the same slide and showed an autostereogram in polarized stereo for those who have never been able to free-view them.

- "From bench to bedside: stereoscopic imaging in experimental and clinical oncology" by Justus llgner (Aachen University Hospital, Germany). Justus' presentation included a very realistic (and gigantic, holodeck-esque stereoscopic) projection of inner-ear surgery.

The prizes were specially autographed copies of the new book Inventing the Movies: Hollywood's epic battle between innovation and the status quo, from Thomas Edison to Steve Jobs, by Scott Kirsner, very kindly donated by the author.

On Wednesday evening, the Electronic Imaging Symposium Reception was also the source of some 3D fun. DepthQ Stereoscopic and NVIDIA setup two largescreen demonstrations of 3D gaming using a pair of DepthQ HD projectors and suitable gaming PCs. The setup of Guitar Hero in 3D was particularly popular - 
with various attendees kitted out with the wireless guitar and wireless NVIDIA 3D glasses. Rob Labbe was also wandering the floor shocking attendees with his anaglyph 3D contact lenses.

Many individuals and companies contributed in various ways to make this year's SD\&A conference very successful:

- This year's conference was sponsored by IMAX Corporation (Mississauga, Canada). Conference sponsorship is a valuable way for companies to support the running of the conference and to gain marketing exposure. IMAX is at the forefront of stereoscopic developments, and we thank them for their support.

- We also appreciate the support of this year's stereoscopic projection sponsors: DepthQ Stereoscopic (Bellevue, Washington), JVC Professional (Cypress, California), Christie Digital (Cypress, California), and Kerner Optical Research and Development (San Rafael, California). The ability to present high-quality large-screen stereoscopic images and video at the conference is vital to the conference's success. This year's setup was again a feast for both eyes.

The two stereoscopic projection systems set up in the SD\&A conference room were: a Christie Digital "S+6K" projector (1400×1050 resolution, 3 chip DLP) projecting onto a $8 \times 6$ foot rear-screen outputting frame-sequential circularly polarized 3D (at up to $120 \mathrm{~Hz}$ ), by way of an active polarization modulator, and a stereo-pair of JVC "DLA-RS2" projectors (1920×1080 resolution, 3 chip LCOS) projecting onto a $8 \times 4.5$ foot rear-screen. Both projection systems output circularly polarized full-color 3D images and video, and members of the audience were provided with circularly polarized 3D glasses. DepthQ Stereoscopic provided a pair of DepthQ stereoscopic media servers (one for each stereoscopic projection system) for playback of all of the stereoscopic video content shown during the 3D Theatre and at many other times during the conference. Kerner Optical R\&D provided the $8 \times 6$ foot rear-projection screen, 3D demultiplexer, and DVD player. Particular thanks go to: Brad Nelson and David Mark from Kerner Optical; Chris Ward, Michal Husak, and Dan Lawrence from DepthQ Stereoscopic; Rod Sterling from JVC Professional; and Wayne Bickley from Christie Digital.

- We thank our media sponsors who help promote the conference: Stereo World magazine, Veritas et Visus, 3D BizEx, Meant to be Seen 3D, and Dimension 3.

- We very much appreciate the dedicated support of Stephan R. Keith (SRK Graphics Research), who had a multi-tasked role at this conference, helping support the AV needs of all of our presenters, controlling the room lights, adjusting the three sound mixer desks, handling the microphones, and running the video cameras. We have no idea how all this can be done by one person, but he did it wonderfully! Stephan also edited some of the conference videos released on the conference website this past year. 
- We are grateful to all of the providers of 3D content for the 3D Theatre session, for allowing their content to be shown to the conference audience.

- Thanks go to the demonstration session presenters for bringing equipment to show. Quite a lot of equipment traveled from overseas, making the contribution to the meeting particularly worthy of additional praise.

- Thanks go to James Tam for making a concerted effort to locate photographs from the early Stereoscopic Displays and Applications conferences (and predecessor conferences). Unfortunately, what we did find is that despite this being an imaging conference, it appears that not many people transferred this knowledge into practice since we weren't able to find many photos from those early conferences. Fortunately, Andrew Woods did have some photographs from the 1991 SD\&A conference (which were shown during the Monday night banquet at BoTown), and David Starkman (Reel 3D, California) recorded some 3D video using a Toshiba 3D camcorder during the 1992 SD\&A conference (which we showed on Monday during one of the technical program breaks).

- The conference committee plays an important role throughout the year, ensuring the correct technical direction of the meeting. Sincere thanks go to Neil Dodgson, Gregg Favalora, Takashi Kawai, Janusz Konrad, Shojiro Nagata, Vivian Walworth, Chris Ward, and Michael Weissman.

- Thanks are also due to the staff at IS\&T and SPIE who were instrumental in helping to organize the meeting.

- Most importantly, we thank the conference authors and attendees, who ultimately made this meeting such a successful event. Thanks especially to those who travel a long way to join us each year.

Two members of our committee received awards at the symposium. John Merritt was elected as an SPIE Fellow for his contribution to stereoscopic imaging over more than two decades. Vivian Walworth was awarded the IS\&T President's Medal for her lifetime's contribution to that society. We congratulate both of them on these well-deserved awards.

John Merritt has chaired the conference since its inception. Following this highly successful 20th annual conference, he is now stepping down from the conference chair role to be a member of the conference committee, where he can continue to provide wisdom and advice. Neil Dodgson will join Andrew Woods and Nick Holliman as the conference chairs for 2010.

Selected papers in this proceedings volume have been peer reviewed in full. This process was initiated, last year, to facilitate the improved quality of the proceedings, provide authors with constructive feedback on their submissions, and provide academic authors with additional recognition for their publications. Peer-reviewed publications are becoming increasingly important in academic circles worldwide, and the SD\&A conference wishes to remain the most relevant place for stereoscopic imaging papers to be published. Authors were asked to request full peer review. This year, two reviewers were sought for each paper for 
which peer review was requested. A single-blind review process was conducted for those papers, and authors were given a two-week window to respond to the reviewer comments. The chairs reviewed the author responses to the reviews and decided whether the responses to the reviewer comments justified the paper being classified as a peer-reviewed technical paper. This year the peer reviewed papers were:

- "Stereoscopic display technologies and rendering approaches for neurosurgical visualization," Jeremy R. Cooperstock, Guang-Yu Wang, McGill Univ. (Canada) [7237-02]

- "Investigating measures of visual fatigue and visual discomfort with (auto)stereoscopic displays: optometric tests and self-report," Marc Lambooij, Wijnand A. ljsselsteijn, Technische Univ. Eindhoven (Netherlands);

Ingrid E. J. Heynderickx, Philips Research (Netherlands) [7237-21]

- "Evaluation of stereoscopic 3D displays for image analysis tasks," Elisabeth Peinsipp-Byma, Ralf Eck, Nils Rehfeld, Fraunhofer-Institut für Informations-und Datenverarbeitung (Germany) [7237-22]

- "The compatibility of LCD TVs with time-sequential stereoscopic 3D visualization," Andrew J. Woods, Adin Sehic, Curtin Univ. of Technology (Australia) [7237-24]

- "Stereoscopy in cinematographic synthetic imagery," Jonathan Eisenmann, Rick Parent, The Ohio State Univ. (United States) [7237-42]

- "Super multi-view display with 128 viewpoints and viewpoint formation," Yasuhiro Takaki, Tokyo Univ. of Agriculture and Technology (Japan) [7237-72]

A quick word about a 3D myth that is routinely repeated in the media and that also surfaced a few times during the conference: The myth is that the 3D movies in the 1950's were shown in anaglyph - NOT TRUE... Quoting the website of the 3D Film Preservation Fund: "Except for a few short films presented in anaglyph form in the early months of 1953 (not widely seen), all of the features, shorts, and cartoons exhibited in commercial theaters from 1952 through 1955 were projected using polarized light. The glasses had colorless lenses like today's major 3D films. When anaglyph comics appeared in the last quarter of 1953, the colored 3D glasses became commonplace. Fact is, colored lenses are much more memorable than colorless (polarized) lenses used to view 3D films." ("Top 10 3-D Myths," 3-D Film Preservation Fund, www.3dfilmpd.org.)

Conference activities do not stop at the end of the January meeting. The SD\&A conference website provides a focus for conference activities during the time between conferences. We are seeking abstracts for the 2010 conference, with a deadline in June 2009; see the website for details and deadlines. You can join the conference mailing list to receive conference announcements; visit the SD\&A conference website for details. The website has an extensive collection of photographs highlighting the activities of past conferences. In addition, the website hosts the stereoscopic virtual library, which contains several historically important books that have been digitized, in full, into PDF format, and are 
available for free download. Visit the website to gain an understanding of the past, present, and future of stereoscopic imaging and, most of all, think now about submitting a paper or attending next year's conference. The Stereoscopic Displays and Applications conference website is located at:

\section{www.stereoscopic.org}

Next year, the 21st conference will be held for three days in the period 17-21 January 2010, at the San Jose McEnery Convention Center, San Jose, California, as part of the 2010 IS\&T/SPIE Electronic Imaging: Science \& Technology Symposium. Photonics West will be held in San Francisco in late January 2010. The 2010 SD\&A conference will continue a tradition of presenting and demonstrating the latest technologies relevant to stereoscopic displays and applications. Please consider attending, presenting, or demonstrating at the 2010 Stereoscopic Displays and Applications conference. We hope to see you there!

Andrew J. Woods Nicolas S. Holliman John O. Merritt 


\section{A few words from John Merritt, founding chair of SD\&A}

Before 1990, the series of annual conferences on 3D imaging and display technologies were part of the SPIE OE/Lase symposium, held in the Los Angeles area. At the end of the 1989 conference, Woodrow Robbins asked if I would be willing to co-chair the 1990 3D conference, as he was going on sabbatical.

I was happy to accept, and worked with SPIE and SPSE (now known as IS\&T) to make a few changes that would help raise the profile of the conference: first, my 1990 co-chair Scott Fisher and I renamed the conference "Stereoscopic Displays and Applications" to emphasize applications of 3D as well as 3D display technologies; second, we moved the conference to a new venue in the San Francisco area-the symposium on Electronic Imaging Science and Technology, jointly sponsored by SPIE and SPSE; and third, we instituted the popular "demo session" at the end of the conference, so attendees could have hands-on experience with the displays and applications discussed in the paper sessions.

At our first demo session in 1990, I remember a long line of people waiting to try out Steve Martin's motorized pan/tilt stereo camera, which was slaved to a headtracked stereoscopic head-mounted display (HMD). The setup allowed a user to look around the room from a viewpoint 20 feet away, literally an "out of body experience," where they could see themselves in 3D as "another person in the room" wearing the HMD. Since that first demo in 1990, many attendees have had a chance to see prototypes of cutting-edge stereoscopic technologies under development.

The past twenty years have been a marvellous experience, a chance to get to know so many colleagues and see our annual gathering become the premiere conference for stereoscopic researchers, developers, students, artists, and 3D enthusiasts. Its lasting success is due in large part to the contributions of Andrew Woods, who first attended SD\&A in 1991 as a young student from Curtin University in Perth, Australia. Andrew rose through the ranks from committee member to lead co-chair, created and has tirelessly maintained the SD\&A conference website (http://www.stereoscopic.org), instituted the popular "3D Theater" and turned the informal dinner on Monday evening into an SD\&A institution: the popular annual banquet at the local BoTown restaurant. Andrew also instituted various discussion panels and keynotes, which were also key factors in the everincreasing success of the SD\&A conference, year after year.

However, SD\&A could never have succeeded for as long as it has without the diligent efforts of all the program committee members, co-chairs, authors, and of course, the multitude of participants who have attended sessions year after year. Over these two decades, I have also come to know, and cannot thank enough, 
the many people at SPIE and IS\&T who provide superlative conference logistics and special A/V support for our 3D-display needs.

Two of our colleagues on this twenty-year journey are no longer with us, and we will always miss their bright enthusiastic presence that enlivened our conferences in the past. We dedicate these Proceedings of SD\&A XX to the memory of our fallen friends, Steve Benton (SD\&A co-chair 2000-2004) and Lew Stelmach (SD\&A committee 2003-2005).

As the SD\&A conference enters its third decade, I am stepping down as SD\&A co-chair, and Neil Dodgson is joining Andrew Woods and Nick Holliman as our new co-chair. In my new role as program committee member, I look forward to watching SD\&A continue to grow far into the 21 st century on the rising tide of stereoscopic enthusiasm.

See you next year at SD\&A XXI!

John O. Merritt 
Stereoscopic Displays and Applications XX (2009) Official Conference Sponsor:

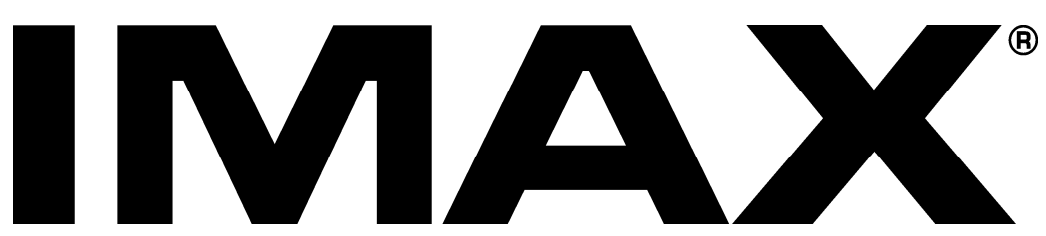

Projection Sponsors:
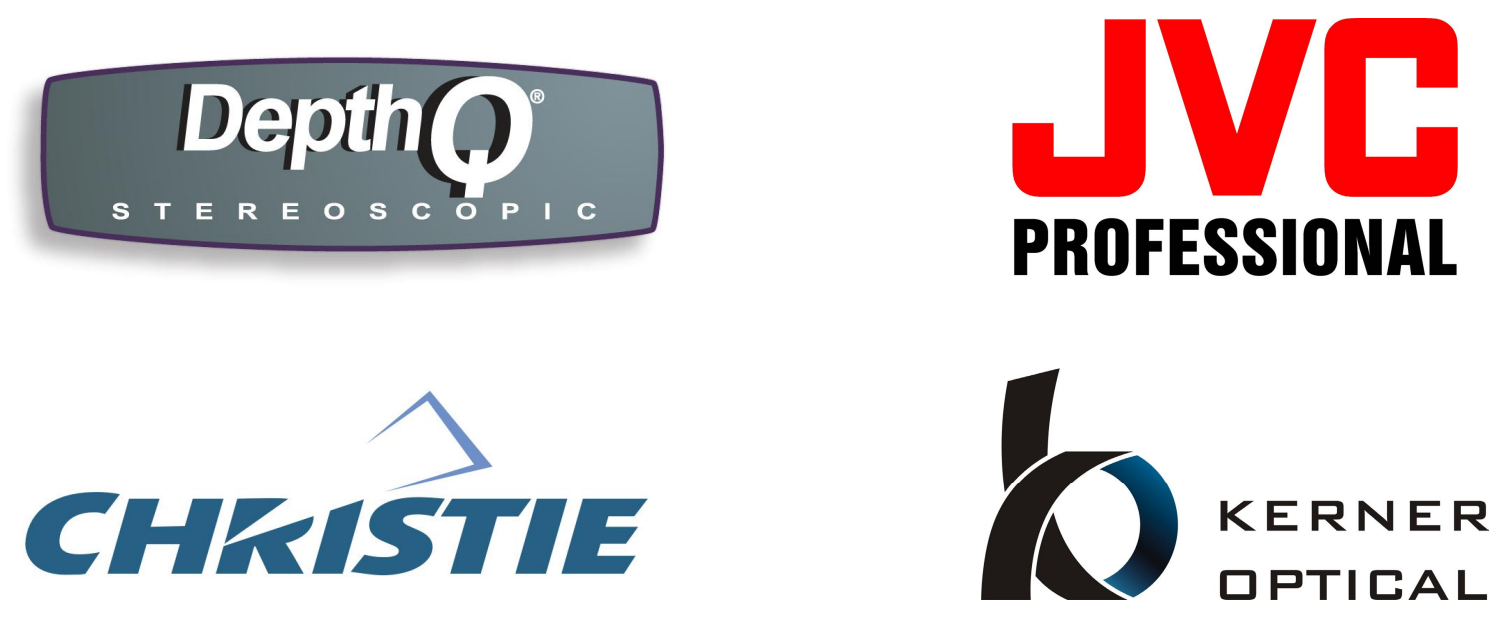
Downloaded From: https://www.spiedigitallibrary.org/conference-proceedings-of-spie on 26 Apr 2023

Terms of Use: https://www.spiedigitallibrary.org/terms-of-use 